\title{
Report on the European Residents in Plastic Surgery Meeting 2015
}

\section{Carlo Melloni}

Plastic and Reconstructive Surgery, University of Palermo, 90133 Palermo, Italy

Address for correspondence: Dr. Carlo Melloni, Plastic and Reconstructive Surgery, University of Palermo, 90133 Palermo, Italy. E-mail: carlomelloni.unipa@gmail.com

As the chairman of the 2015 European Residents in Plastic Surgery (EuRePS) Meeting and on behalf of the organizing committee, it is a pleasure for me to describe the emotions that flew through that magic days.

The setting was Favignana, an enchanting, whimsical, harsh and welcoming island in the Mediterranean Sea. About 150 participants from all over Europe and beyond have invaded the venue of the meeting, an old tuna-fish factory called "Tonnara Florio".

Countdown to suspense and video with special effects introduced the EuRePS Meeting's opening, on 18th June 2015. The conference, entirely dedicated to European Residents in Plastic Surgery, has been organized by the School of Specialization in Plastic, Reconstructive and Aesthetic Surgery of the University of Palermo.

The enthusiasm is sky high and the focus is at the top. Off we go!

With their communications and high quality scientific works, the residents gave birth to four days of intense debate on the most advanced researches in plastic surgery.

Sharing knowledge and setting new collaborations were the main goals of the meeting. Attendants presented their works, both in podium and in poster presentation, and residents also had the opportunity to be moderators for one day tutored by the Directors of the Italian Schools of Plastic Surgery.

The poster session was one of the greatest innovations. With a fresh and informal format, the poster session was arranged as a short-oral-presentation during an aperitif. Speakers presented their works in three minutes enjoying

\begin{tabular}{|l|l|}
\hline \multicolumn{2}{|c|}{ Access this article online } \\
\hline Quick Response Code: & Website: \\
\hline & http://www.parjournal.net \\
\cline { 2 - 3 } & \\
\hline
\end{tabular}

together with the attendant a glass of icy-white-wine.

The Keynote Lectures of the invited "Special Guest" such as Roy De Vita (Rome), Jaume Masia (Barcelona), Fabio Santanelli di Pompeo (Rome), Jan Vranckx (Leuven) and Salvatore D'Arpa (Gent) have enriched the scientific program with important practical information, charming the participants with their "ars oratoria".

The event ended on Sunday 21st with a space reserved for the projects of the Italian Society of Plastic, Reconstructive and Aesthetic Surgery (SICPRE) dedicated to residents and the awards for the best five works here published in Plastic and Aesthetic Research Journal.

The EuRePS Award for the best communication went to Margot Den Hondt, resident in Leuven (Belgium), who will have the opportunity to participate for free at the upcoming EuRePS meeting in Brussels in 2016.

In this way, four unforgettable days of science, friendship and fun come to the end: the perfect mix that made this event unique.

We are looking at the future; we are looking for a new way to arrange meetings in a different format: less formal, relaxed atmosphere and smart presentations with lots of tips and tricks messages to take home. The future is now!

\section{Financial support and sponsorship}

Nil.

\section{Conflicts of interest}

There are no conflicts of interest.

This is an open access article distributed under the terms of the Creative Commons Attribution-NonCommercial-ShareAlike 3.0 License, which allows others to remix, tweak and build upon the work non-commercially, as long as the author is credited and the new creations are licensed under the identical terms.

For reprints contact: service@oaepublish.com

How to cite this article: Melloni C. Report on the European Residents in Plastic Surgery Meeting 2015. Plast Aesthet Res 2016;3:220.

Received: 12-05-2016; Accepted: 13-06-2016 